American Journal of Applied Sciences 8 (2): 141-146, 2011

ISSN 1546-9239

(C) 2010 Science Publications

\title{
Evaluation of Critical Clearing Time of Power System Equipped with a Static Synchronous Compensator
}

\author{
Prechanon Kumkratug \\ Department of Electrical Engineering, Faculty of Engineering at Si Racha, \\ Kasetsart University, 199 M.6, Tungsukhla, Si Racha, \\ Chonburi, 20230, Thailand
}

\begin{abstract}
Problem statement: The critical clearing time provides very important role of the robustness in power system. The Static Synchronous Compensator (STATCOM) has been accepted to be equipped in modern power system. This study presents the method to evaluate the Critical Clearing Time (CCT) of the system equipped with a Static Synchronous Compensator (STATCOM). Approach: The parameter on STATCOM is modeled in energy function. The presented energy function is applied to determine CCT of the system. The verification of the proposed method is tested on sample system. Results: The maximum generator rotor angle of the faulted system without a STATCOM is continuously oscillation and the maximum value is much more than the system with a STATCOM. Conclusion: STATCOM based the proposed nonlinear control can damp power system oscillation.
\end{abstract}

Key words: Critical Clearing Time (CCT), power system stability, FACTS devices, Static Synchronous Compensator (STATCOM), Single Machine Infinite Bus (SMIB), energy function, voltage injection, voltage source, short circuit

\section{INTRODUCTION}

Now, power engineers are much more concerned about stability problem due to the complicated network of power system. A number of Flexible AC Transmission System (FACTS) controllers, based on the rapid development of power electronics technology, have been proposed for power flow control in steady state and dynamic state. (Abdullah et al., 2009; Osuwa and Igwiro, 2010; Zarate-Minano et al., 2010). They have proposed many methods to improve stability of power system such as load shedding, High Voltage Direct Current (HVDC), Flexible AC Transmission system (FACTS), (Hannan et al., 2009; Magaji and Mustafa, 2009; Mustafa and Magaji, 2009; Omar et al., 2010; Kumkratug, 2010).

The STATCOM can electrically mimic reactor and capacitor by injecting a shunt current in quadrature with the line voltage. The reactive power (or current) of the STATCOM can be adjusted by controlling the magnitude and phase angle of the output voltage of the shunt converter (Nabhan and Abdallah, 2010; Nisar et al., 2009; Rosli Omar et al., 2010; Chatchanayuenyong, 2009).

One of the most important parts of transient stability is to estimate the Critical Clearing Time (CCT). Many previous researches present CCT improvement of power system with FACTS devices by using time domain simulation. To asset the CCT by using time domain simulation method, it is time consuming process because it requires numerous of scenarios of the fault occurrence A Static Synchronous Compensator (STATCOM) is a member of the FACTS family that is connected in shunt with power system. The STATCOM consists of a solid state voltage source converter with GTO thyristor switches or other high performance of semi-conductor and transformer.

This study proposes the energy function of a power system with a STATCOM. The CCT of the system with a STATCOM is estimated from the proposed energy function and it is compared with the time domain simulation method. In addition, this study will further develop control strategy of the STATCOM.

\section{MATERIALS AND METHODS}

Mathematical model: Figure 1a shows the single line diagram of the Single Machine Infinite Bus (SMIB) system with a STATCOM at bus $m$. First consider the system without the STATCOM and the corresponding equivalent circuit is shown in Fig. $1 b$. Here $X_{1}$ is the equivalent reactance between the machine internal bus and the bus $m$ and $X_{2}$ is the equivalent reactance between bus $m$ and the infinite bus. The generator is represent by a constant voltage source (E') behind transient reactance. The equivalent circuit of the system with a STATCOM is shown in Fig. 1c where the STATCOM is represented by a shunt current source. 
Am. J. Applied Sci., 8 (2): 141-146, 2011

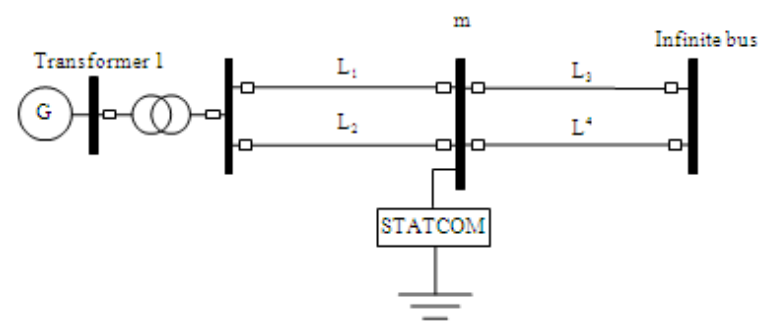

(a)

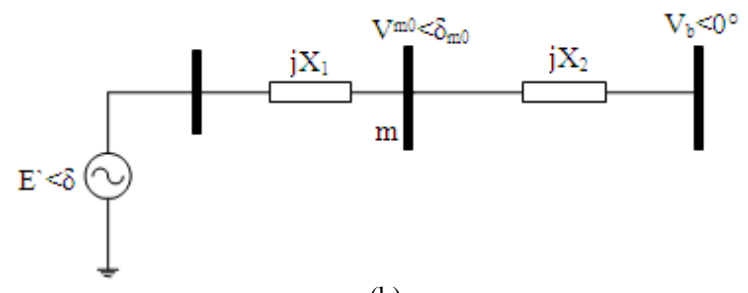

(b)

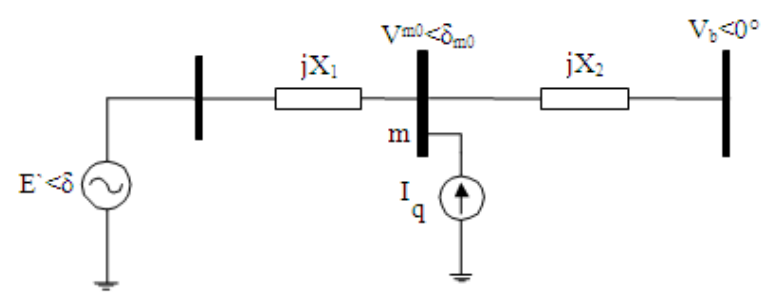

(c)

Fig. 1: A Single Machine Infinite Bus (SMIB) system with STATCOM; (a) A single line diagram; (b) Equivalent circuit of SMIB system without STATCOM; (c) Equivalent circuit of SMIB system with a STATCOM represented by a current injection model

Note that the injected current of the STATCOM is always in quadrature with its terminal voltage. The dynamics of the generator, without the STATCOM, can be expressed by the following differential equations:

$\dot{\delta}=\omega$

$\dot{\omega}=\frac{1}{\mathrm{M}}\left[\mathrm{P}_{\mathrm{m}}-\mathrm{P}_{\mathrm{e} 0}\right]$

Here $\delta, \omega, \mathrm{P}_{\mathrm{m}}$ and $\mathrm{M}$ are the rotor angle, speed, input mechanical power and moment of inertia, respectively, of the generator. $\mathrm{P}_{\mathrm{e} 0}$ is output electrical power of generator without the STATCOM and is given by:

$\mathrm{P}_{\mathrm{eo}}=\frac{\mathrm{E}^{\prime} \mathrm{V}_{\mathrm{mo}}}{\mathrm{X}_{1}} \sin \left(\delta-\delta_{\mathrm{mo}}\right)=\mathrm{P}_{\mathrm{e} 0}^{\max } \sin (\delta)$
Here $\mathrm{P}_{\mathrm{e} 0}^{\max } \mathrm{V}_{\mathrm{m} 0}, \delta_{\mathrm{m} 0}$ represent the voltage magnitude and angle at bus $\mathrm{m}$ without the STATCOM and are given by:

$\delta_{\mathrm{m} 0}=\tan ^{-1}\left[\frac{\mathrm{X}_{2} \mathrm{E}^{\prime} \sin \delta}{\mathrm{X}_{2} \mathrm{E}^{\prime} \cos \delta+\mathrm{X}_{1} \mathrm{~V}_{\mathrm{b}}}\right]$

$\mathrm{V}_{\mathrm{m} 0}=\left(\frac{\mathrm{X}_{2} \mathrm{E}^{\prime} \cos \left(\delta-\delta_{\mathrm{m}}\right)+\mathrm{X}_{1} \mathrm{~V}_{\mathrm{b}} \cos \delta_{\mathrm{m}}}{\mathrm{X}_{1}+\mathrm{X}_{2}}\right)$

In general form, Eq. 1-2 can be written as:

$\dot{\mathrm{x}}=\mathrm{f}_{0}(\mathrm{x})$

Where:

$$
\mathrm{x}=\left[\begin{array}{l}
\mathrm{x}_{1} \\
\mathrm{x}_{2}
\end{array}\right]=\left[\begin{array}{l}
\delta \\
\omega
\end{array}\right]
$$

and:

$$
f_{0}(x)=\left[\begin{array}{l}
f_{01}(x) \\
f_{02}(x)
\end{array}\right]=\left[\begin{array}{c}
\omega \\
P_{m}-P_{e 0} \\
M
\end{array}\right]
$$

Now, consider the system with the STATCOM at bus $\mathrm{m}$ as shown Fig. 1c. The injected current of the STATCOM for capacitive mode of operation can be expressed as

Figure 1 A Single Machine Infinite Bus (SMIB) system with STATCOM; (a) A single line diagram; (b) Equivalent circuit of SMIB system without STATCOM; (c) Equivalent circuit of SMIB system with a STATCOM represented by a current injection model:

$\mathbf{I}_{\mathrm{q}}=\mathrm{I}_{\mathrm{q}} \angle \delta_{\mathrm{m}}-90^{\circ}$

With the STATCOM, the voltage magnitude and angle at bus $\mathrm{m}$ can be written as:

$$
\begin{aligned}
\delta_{\mathrm{m}}= & \tan ^{-1}\left[\frac{\mathrm{X}_{2} \mathrm{E}^{\prime} \sin \delta}{\mathrm{X}_{2} \mathrm{E}^{\prime} \cos \delta+\mathrm{X}_{1} \mathrm{~V}_{\mathrm{b}}}\right] \\
\mathrm{V}_{\mathrm{m}} & =\left(\frac{\mathrm{X}_{2} \mathrm{E}^{\prime} \cos \left(\delta-\delta_{\mathrm{m}}\right)+\mathrm{X}_{1} \mathrm{~V}_{\mathrm{b}} \cos \delta_{\mathrm{m}}}{\mathrm{X}_{1}+\mathrm{X}_{2}}\right) \\
& +\left(\frac{\mathrm{X}_{1} \mathrm{X}_{2}}{\mathrm{X}_{1}+\mathrm{X}_{2}} \mathrm{I}_{\mathrm{q}}\right)
\end{aligned}
$$

Note that $\delta_{\mathrm{m}}$ of (8) is exactly the same as $\delta_{\mathrm{m} 0}$ of (4). That is the STATCOM current does not change the angle of the voltage at bus $\mathrm{m}$. However, the voltage 
magnitude of bus $m$ depends on the STATCOM current $I_{q}$ as can be seen in (9). Note that the first term on the right hand side of (9) is the same as $\mathrm{V}_{\mathrm{m} 0}$ of (5) and the second term represent the contribution of the STATCOM current. Thus $\mathrm{V}_{\mathrm{m}}$ can be expressed as:

$\mathrm{V}_{\mathrm{m}}=\mathrm{V}_{\mathrm{m} 0}+\mathrm{C}_{1} \mathrm{I}_{\mathrm{q}}$

where, $C_{1}=\frac{X_{1} X_{2}}{X_{1}+X_{2}}$

Using Fig. 1c, the output electrical power $\mathrm{P}_{\mathrm{e}}$ of generator, with the STATCOM, can be written as:

$\mathrm{P}_{\mathrm{e}}^{\mathrm{sh}}=\frac{\mathrm{E}^{\prime} \mathrm{V}_{\mathrm{m}}}{\mathrm{X}_{1}} \sin \left(\delta-\delta_{\mathrm{m}}\right)$

Using Eq. 10-11), $\mathrm{P}_{\mathrm{e}}^{\text {sh }}$ can be expressed as:

$\mathrm{P}_{\mathrm{e}}=\mathrm{P}_{\mathrm{e} 0}+\mathrm{C}_{2} \mathrm{I}_{\mathrm{q}} \sin \left(\delta-\delta_{\mathrm{m}}\right)$

where, $\mathrm{C}_{2}=\frac{\mathrm{E}^{\prime} \mathrm{C}_{1}}{\mathrm{X}_{1}}$

It may be mentioned here that the above equations are derived for capacitive mode of operation of the STATCOM. For inductive mode of operation, $I_{q}$ in (9), (10) and (12) needs to be replaced by $-\mathrm{I}_{\mathrm{q}}$. Thus the dynamic equations of the generator with the STATCOM becomes:

$\dot{x}=f(x, u)=f_{0}(x)+u f_{1}(x)$

where, $\mathrm{u}=\mathrm{I}_{\mathrm{q}}$

and:

$$
f_{1}(x)=\left[\begin{array}{l}
f_{11}(x) \\
f_{12}(x)
\end{array}\right]=\left[\begin{array}{c}
0 \\
\frac{-C_{2} \sin \left(\delta-\delta_{m}\right)}{M}
\end{array}\right]
$$

The system states $\mathrm{x}$ and function $\mathrm{f}_{0}$ are already defined in (6).

Energy function: The energy function $\left(\mathrm{V}_{\mathrm{sh}}\right)$ of a power system with a STATCOM written by:

$$
\mathrm{V}_{\mathrm{sh}}(\delta, \omega)=\mathrm{V}_{\mathrm{k}}(\omega)+\mathrm{V}_{\mathrm{p} 0}(\delta)+\mathrm{V}_{\mathrm{p}}^{\mathrm{sh}}(\delta)+\mathrm{V}_{\mathrm{c}}(\delta)
$$

Here $V_{k}$ is kinetic energy, $V_{p 0}$ is the potential energy of the system without a STATCOM, $V_{p}^{\text {sh }}$ is the additional component of potential energy of a STATCOM and $V_{c}$ is the constant energy at the post fault equilibrium point of machine angle $\left(\delta_{\mathrm{s}}\right)$ and speed $\left(\omega_{\mathrm{s}}=0\right)$. The first integral of the motion of (13) constitutes an energy function given by (Omar et al., 2010):

$$
\begin{aligned}
& \mathrm{V}_{\mathrm{sh}}(\delta, \omega)=\left[\int_{0}^{\omega} \mathrm{M} \omega \mathrm{d} \omega\right]-\left[\int_{\delta_{\mathrm{s}}}^{\delta} \mathrm{Mf}_{0}(\mathrm{x}) \mathrm{d}(\mathrm{x})\right]- \\
& {\left[\int_{\delta_{\mathrm{s}}}^{\delta} \operatorname{Muf}_{1}(\mathrm{x}) \mathrm{d}(\mathrm{x})\right.}
\end{aligned}
$$

From (6), 12-13 the (16) can be written as:

$$
\begin{aligned}
& \mathrm{V}_{\mathrm{sh}}(\delta, \omega)=\left[\int_{0}^{\omega} \mathrm{M} \omega \mathrm{d} \omega\right]+\left[\int_{\delta_{\mathrm{s}}}^{\delta}\left[-\mathrm{P}_{\mathrm{m}}+\mathrm{P}_{\mathrm{e} 0}\right] \mathrm{d} \delta\right]+ \\
& {\left[\int_{\delta_{\mathrm{s}}}^{\delta} \mathrm{C}_{2} \mathrm{I}_{\mathrm{q}} \sin \left(\delta-\delta_{\mathrm{m}}\right) \mathrm{d} \delta\right]}
\end{aligned}
$$

The location of a STATCOM should be placed at the location where it provides the maximum output electrical power. With $\mathrm{E}^{\prime} \cong \mathrm{V}_{\mathrm{b}}$ and $\mathrm{X}_{1}=\mathrm{X}_{2}$, the output electrical power has the maximum value.

From (8), the value of $\delta_{\mathrm{m}}$ is given by:

$\delta_{\mathrm{m}} \cong 2 \delta$

From (17), the energy function $\left(\mathrm{V}_{\mathrm{sh}}\right)$ of a power system with a STATCOM is given by:

$$
\begin{aligned}
& \mathrm{V}_{\mathrm{sh}}(\delta, \omega)=\left[\frac{1}{2} \mathrm{M} \omega\right]+\left[-\mathrm{P}_{\mathrm{m}} \delta+\mathrm{P}_{\mathrm{e} 0}^{\max } \cos \delta\right]+ \\
& {\left[\mathrm{C}_{3} \mathrm{I}_{\mathrm{q}} \cos \delta / 2\right]+\mathrm{V}_{\mathrm{c}}}
\end{aligned}
$$

The first bracket represents the kinetic energy $\left(\mathrm{V}_{\mathrm{k}}\right)$, the second bracket represents the potential energy $\left(\mathrm{V}_{\mathrm{p} 0}\right)$ without a STATCOM and the third bracket represents the proposed potential energy function $\mathrm{V}_{\mathrm{p}}^{\text {sh }}$ of STATCOM given by:

$\mathrm{V}_{\mathrm{p}}^{\mathrm{sh}}=\mathrm{C}_{2} \mathrm{I}_{\mathrm{q}} \cos (\delta / 2)$

The proposed energy function will used for transient stability assessment of a power system with a STATCOM and it is also used for deriving the control strategy.

The continuous nonlinear control of the STACOM is given by:

$\mathrm{I}_{\mathrm{q}}=\mathrm{k} \omega \sin \delta$ 


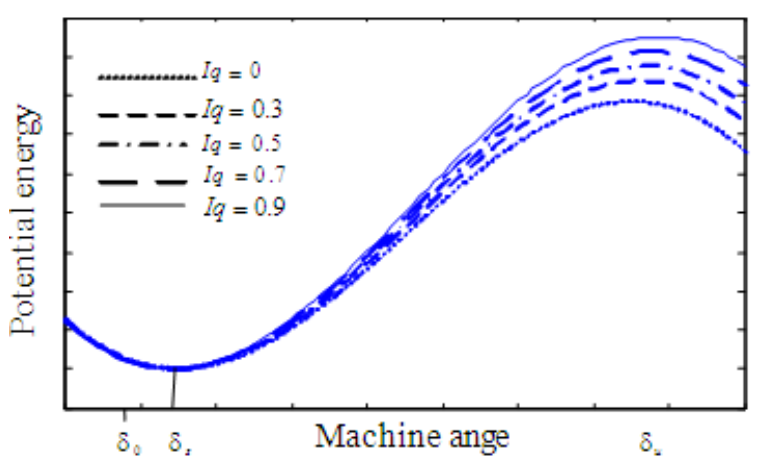

Fig. 2: Energy function against machine angle with various cases

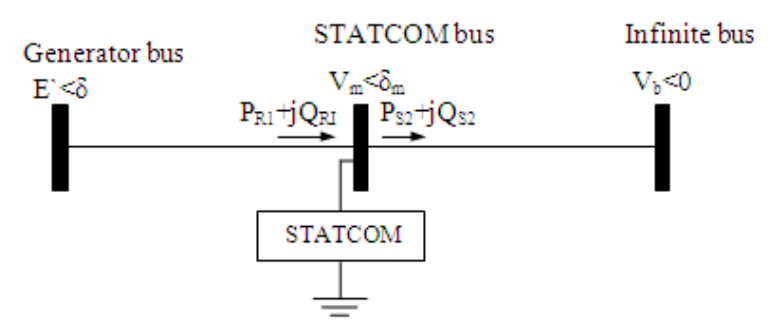

Fig. 3: Locally measurable signal at location of STATCOM

However, in this study, the proposed potential energy will be further used for develop the control strategy of a STATCOM. Figure 2 shows variation of $\mathrm{V}_{\mathrm{p}}^{\text {sh }}$ against $\delta$. Suppose that the system with a STATCOM is subjected to severe disturbance. With $\mathrm{I}_{\mathrm{q}}=0$ machine angle will increase from prefault stable equilibrium point $\left(\delta_{0}\right)$ to any machine angle $\left(\delta>\delta_{\mathrm{s}}>\delta_{0}\right)$ corresponding the potential gets increase. If machine angle reaches at the unstable equilibrium point $\left(\delta=\delta_{\mathrm{u}}\right)$ the potential energy function has the maximum value. The system is considered as unstable when $\delta>\delta_{u}$ and $\mathrm{V}_{\mathrm{P}}(\delta)<\mathrm{V}_{\mathrm{p}}\left(\delta_{\mathrm{u}}\right)$. It can be seen from the Figure that the maximum potential energy and unstable equilibrium point gets increase as the $I_{q}$ is increased. Thus for the first swing stability improvement the maximum of Iq should be used and then the $\mathrm{I}_{\mathrm{q}}$ is controlled by (20) given by:

$I_{q}=\left\{\begin{array}{l}I_{q}^{\max } \quad \text { for first swing } \\ k \omega \sin \delta \text { afterwards }\end{array}\right.$

The machine angle and speed required to control the STATCOM are estimated from some local measurements. The measured data used in this study are the incoming and outgoing active and reactive power flows $\left(\mathrm{P}_{\mathrm{R} 1}, \mathrm{Q}_{\mathrm{R} 1}, \mathrm{P}_{\mathrm{S} 2}\right.$ and $\left.\mathrm{Q}_{\mathrm{S} 2}\right)$ at the STATCOM bus and the voltage magnitude $\left(\mathrm{V}_{\mathrm{m}}\right)$ of the bus. The above quantities are clearly leveled in Fig. 3. Note that a lossless STATCOM does not supply or absorb any active power and thus $\mathrm{P}_{\mathrm{R} 1}=\mathrm{P}_{\mathrm{S} 2}$.

The outgoing active and reactive power flows $\left(\mathrm{P}_{\mathrm{S} 2}\right.$ and $\mathrm{Q}_{\mathrm{s} 2}$ ) can be expressed as:

$\mathrm{P}_{\mathrm{s} 2}=\frac{\mathrm{V}_{\mathrm{m}} \mathrm{V}_{\mathrm{b}}}{\mathrm{X}_{2}} \sin \delta_{\mathrm{m}}$ and $\mathrm{Q}_{\mathrm{s} 2}=\frac{\mathrm{V}_{\mathrm{m}}^{2}}{\mathrm{X}_{2}}-\frac{\mathrm{V}_{\mathrm{m}} \mathrm{V}_{\mathrm{b}}}{\mathrm{X}_{2}} \cos \delta_{\mathrm{m}}$

Using (20) and the measured data $\left(\mathrm{P}_{\mathrm{S} 2}, \mathrm{Q}_{\mathrm{S} 2}\right.$ and $\left.\mathrm{V}_{\mathrm{m}}\right)$, the angle $\delta_{\mathrm{m}}$ at the STATCOM bus can be written as:

$\delta_{\mathrm{m}}=\tan ^{-1}\left[\frac{\mathrm{P}_{\mathrm{R} 1}}{\mathrm{~V}_{\mathrm{m}}^{2} / \mathrm{X}_{2}-\mathrm{Q}_{\mathrm{S} 2}}\right]$

Similarly, the incoming active and reactive power flows $\left(\mathrm{P}_{\mathrm{R} 1}\right.$ and $\left.\mathrm{Q}_{\mathrm{R} 1}\right)$ at the STATCOM bus can be written as:

$P_{R 1}=\frac{E^{\prime} V_{m}}{X_{1}} \sin \left(\delta-\delta_{m}\right)$

$Q_{R 1}=\frac{E^{\prime} V_{m}}{X_{1}} \cos \left(\delta-\delta_{m}\right)-\frac{V_{m}^{2}}{X_{1}}$

Again from the measured data $\left(\mathrm{P}_{\mathrm{R} 1}, \mathrm{Q}_{\mathrm{S} 1}\right.$ and $\left.\mathrm{V}_{\mathrm{m}}\right)$ and (23), the machine angle $\delta$ can be written as:

$\delta=\delta_{\mathrm{m}}+\tan ^{-1}\left[\frac{\mathrm{P}_{\mathrm{R} 1}}{\mathrm{Q}_{\mathrm{R} 1}+\mathrm{V}_{\mathrm{m}}^{2} / \mathrm{X}_{1}}\right]$

Once the value of the angle $\delta$ is known, the speed $\omega$ of the generator can be estimated from its time derivative $(\omega=\mathrm{d} \delta / \mathrm{dt})$.

\section{RESULTS}

The proposed control energy function and control strategy of a power system with a STATCOM are tested on system of Fig. 1a. It is considered that a threephase self-clearing type fault appears at bus $\mathrm{m}$. For the Critical Clearing Time (CCT) Assessment, This Study Used The Potential-energy boundary surface (PEBS) method. Figure 4a shows variation curve of the total energy $(\mathrm{V})$ and potential energy $\left(\mathrm{V}_{\mathrm{p}}\right)$ for the system without a STATCOM $\left(\mathrm{I}_{\mathrm{q}}=0\right)$. Figure $4 \mathrm{~b}$ shows variation curve of the total energy $(\mathrm{V})$ and potential energy $\left(\mathrm{V}_{\mathrm{p}}\right)$ for the system with a STATCOM $\left(\mathrm{I}_{\mathrm{q}}=0.3\right)$. Table 1 summarizes the CCT of the system with various rating of a STATCOM. 
Am. J. Applied Sci., 8 (2): 141-146, 2011

Table 1: Improvement of $\mathrm{V}_{\mathrm{P}}^{\text {sh }}$ and $\delta_{\mathrm{u}}$ for various cases of STATCOM

\begin{tabular}{llll}
\hline $\mathrm{Iq}(\mathrm{pu})$ & $\mathrm{V}_{\mathrm{P}}^{\mathrm{sh}}(\mathrm{pu})$ & $\delta_{\mathrm{u}}($ degree$)$ & $\mathrm{CCT}(\mathrm{msec})$ \\
\hline 0 & 1.37 & 150 & $590-591$ \\
0.3 & 1.47 & 152 & $619-620$ \\
0.5 & 1.55 & 154 & $630-631$ \\
0.7 & 1.63 & 153 & $649-650$ \\
0.9 & 1.70 & 157 & $651-652$ \\
\hline
\end{tabular}

Table 2: Damping Improvement with constant $\mathrm{I}_{\mathrm{q}}$

\begin{tabular}{lll}
\hline $\mathrm{Iq}(\mathrm{pu})$ & $\delta_{\max }($ degree $)$ & $\delta_{\min }($ degree $)$ \\
\hline 0.3 & 145.26 & -43.23 \\
0.5 & 135.26 & -44.05 \\
0.7 & 129.95 & -44.90 \\
0.9 & 126.15 & -45.67 \\
0.3 & 145.26 & -43.23 \\
\hline
\end{tabular}

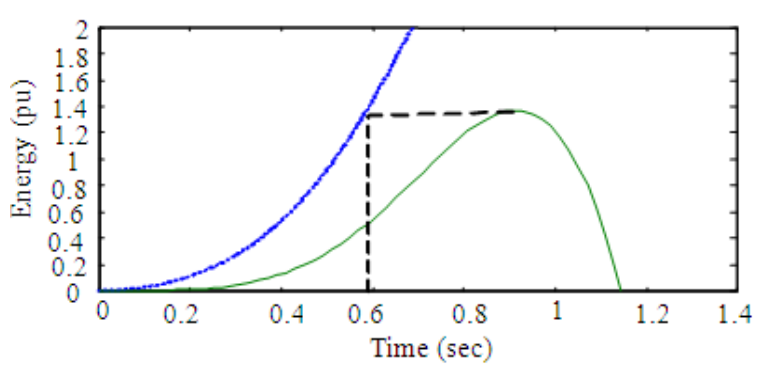

(a)

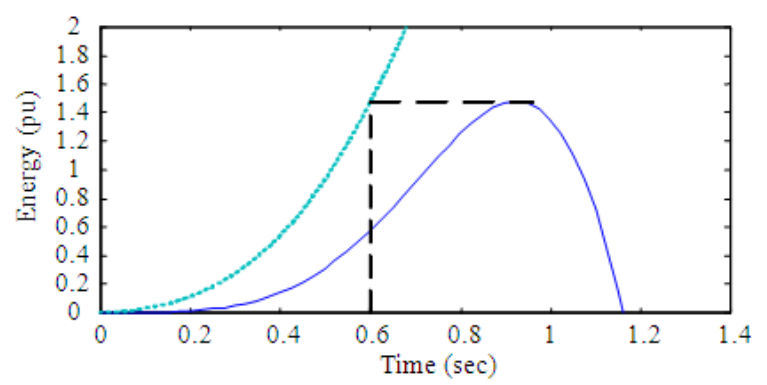

(b)

Fig. 4: Variation of energy function of a power system (a) without STATCOM (b) with a STATCOM

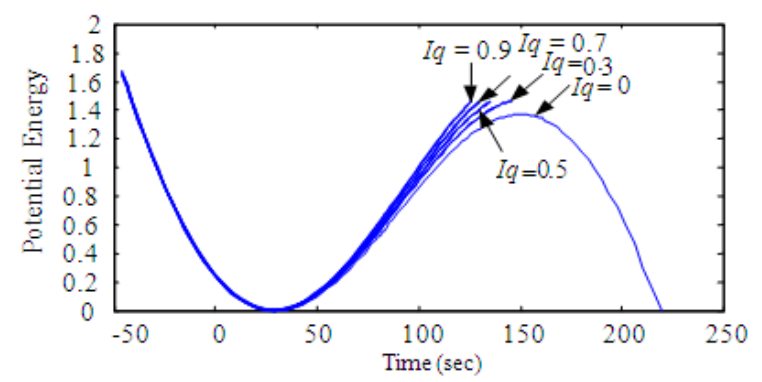

Fig. 5: Potential energy against machine angle with various constant $\mathrm{I}_{\mathrm{q}}$
Table 3: Damping comparison between constant $I_{q}$ and proposed control of $I_{q}$

\begin{tabular}{lllll}
\hline & \multicolumn{2}{l}{ With constant $\mathrm{I}_{\mathrm{q}}$} & \multicolumn{2}{c}{ With proposed control $\mathrm{I}_{\mathrm{q}}$} \\
\cline { 2 - 4 } $\mathrm{I}_{\mathrm{q}}(\mathrm{pu})$ & $\delta_{\max }$ & $\delta_{\max }$ & $\delta_{\max }$ & $\delta_{\max }$ \\
\hline 0.3 & 145.26 & -43.23 & 145.26 & -32.12 \\
0.5 & 135.26 & -44.05 & 135.26 & -32.07 \\
0.7 & 129.95 & -44.90 & 129.95 & -31.50 \\
0.9 & 126.15 & -45.67 & 126.15 & -30.12 \\
\hline
\end{tabular}

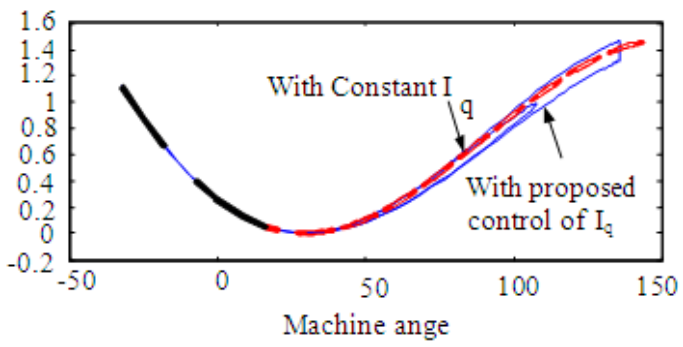

Fig. 6: Variation of Potential energy with constant and proposed control of $\mathrm{I}_{\mathrm{q}}$

Figure 5 shows the variation of potential energy against machine angle with clearing time of fault $\left(\mathrm{t}_{\mathrm{cl}}\right)$ for $610 \mathrm{msec}$ with various cases of $\mathrm{I}_{\mathrm{q}}$. The maximum and minimum of machine angle are summarized in Table 2. Figure 6 shows the swing curve of the system with constant $\mathrm{I}_{\mathrm{q}}=0.3$ and with proposed control. Table 3 summarizes the damping comparison between constant $\mathrm{I}_{\mathrm{q}}$ and proposed control of $\mathrm{I}_{\mathrm{q}}$.

\section{DISCUSSION}

Figure 4 shows that the maximum of $\mathrm{V}_{\mathrm{p}}$ and CCT are around $1.37 \mathrm{pu}$ and $590 \mathrm{msec}$, respectively. However, with $\mathrm{I}_{\mathrm{q}}=0.3 \mathrm{pu}$, the CCT is improve to 620 msec because of the $I_{q}$ help the system increases the potential energy $\mathrm{V}_{\mathrm{p}}^{\mathrm{sh}}$ to $1.47 \mathrm{pu}$. It can be seen from the Table 1 that CCT and maximum of $\mathrm{V}_{\mathrm{p}}^{\text {sh }}$ gets increase as the $I_{q}$ is increased. With $\mathrm{Iq}=0.9 \mathrm{pu}$, the CCT is increased to $650 \mathrm{msec}$.

It can be seen Fig. 5 that without STATCOM, after machine angle reaches maximum, machine angle increases as the potential energy decreases where as the system with $I_{q}=0.3 \mathrm{pu}$, the machine angle decreases as potential energy decreases. It can be seen from the Table that the maximum of machine angle is improved as the rating of $I_{q}$ is increased. However, the minimum of machine angle is not improved.

This study used the nonlinear control $k \omega \sin \delta$ for the multi-swing improvement. It can be seen from the Figure that with the proposed control the minimum machine angle is around -32.12 whereas with constant $\mathrm{I}_{\mathrm{q}}=0.3 \mathrm{pu}$ the minimum machine angle is around -44 . 


\section{CONCLUSION}

This study presents the method to evaluate the Critical Clearing Time (CCT) of the system equipped with a Static Synchronous Compensator (STATCOM). The proposed energy function is used to estimate the CCT. The parameter of the STATCOM is modeled in the potential energy of a power system. It was found that the STATCOM can improve stability of the power system because it can increase the maximum the potential energy and unstable equilibrium point. This study developed the control strategy of the STACOM. The maximum of rating is used for the first swing and non-linear is used for damping improvement. The proposed energy function is then tested on the simple system and it was found that the STATCOM can increase the potential energy and CCT.

\section{REFERENCES}

Abdullah, H., A. Lennie, M. J. Saifuddin and I. Ahmad, 2009. The effect of electrical properties by texturing surface on gaas solar cell efficiency. Am. J. Eng. Applied Sci., 2: 189-193. DOI: 10.3844/ajeassp.2009.189.193

Hannan, M.A., A. Mohamed, A. Hussian and M.A. Dabbay, 2009. Development of the unified series-shunt compensator for power quality mitigation. Am. J. Applied Sci., 6: 978-986. DOI: 10.3844/ajassp.2009.978.986

Nabhan, I. and M. Abdallah, 2010. A novel low-power cmos operational amplifier with high slew rate and high common-mode rejection ratio. Am. J. Eng. Applied Sci., 3: 189-192. DOI: 10.3844/ajeassp.2010.189.192

Magaji, N. and M.W. Mustafa, 2009. Optimal thyristor control series capacitor neuro-controller for damping oscillations. J. Comput. Sci., 5: 980-987. DOI: $10.3844 /$ jcssp.2009.980.987
Mustafa, M.W. and N. Magaji, 2009. Optimal location of static var compensator device for damping oscillations. Am. J. Eng. Applied Sci., 2: 353-359. DOI: 10.3844/ajeassp.2009.353.359

Nisar, M.W., W. Yong-Ji, M. Elahi and I.A. Khan, 2009. Software development effort estimation using fuzzy logic. A case study. Proceeding of the 6th Mexican International Conference on Computer Science, Sept. 26-30 Polytech. Inst., Mexico, pp: 113-120. DOI: 10.1109/ENC.2005.47

Omar, R., N.A. Rahim and M. Sulaiman, 2010. New control technique applied in dynamic voltage restorer for voltage sag mitigation. Am. J. Applied Sci., 3: 42-48. DOI: 10.3844/ajeassp.2010.42.48

Osuwa, J.C. and E.C. Igwiro, 2010. Uninterruptible power supply using solar rechargeable battery. Phys. Int., 1: 77-82. DOI: 10.3844/pisp.2010.77.82

Kumkratug, P., 2010. Application of interline power flow controller to increase transient stability of power system. Journal of Computer Science, 6: 1490-1493. DOI: $10.3844 /$ jcssp.2010.1484.1487

Chatchanayuenyong, T., 2009. A fast series active filter using sliding mode control to correct and regulate unbalance voltage in three-phase system. Am. J. Eng. Applied Sci., 2: 393-398. DOI: 10.3844/ajeassp.2009.393.398

Zarate-Minano, R., T. Van Custsem, F. Milano and A.J. Conejo, 2010. Securing transient stability using time-domain simulations within an optimal power flow. IEEE Trans. Power Syst., 5: 243-253, DOI: 10.1109/TPWRS.2009.2030369 